\title{
Testicular FNAC in Azoospermia
}

\author{
M. Shahab Uddin Ahamad ${ }^{1 *}$ \\ SK Md. Jaynul Islam² \\ Md. Babul Osman Chowdhury ${ }^{3}$ \\ Shireen Akhtar Khanam ${ }^{4}$ \\ ASM Mostaque Ahmed ${ }^{3}$ \\ 'Department of Pathology \\ Cox's Bazar Medical College \\ Cox's Bazar, Bangladesh. \\ ${ }^{2}$ Department of Pathology \\ Armed Forces Medical College. \\ Dhaka, Bangladesh. \\ ${ }^{3}$ Department of Pathology \\ Chattagram Maa-O-Shishu Hospital Medical College \\ Chittagong, Bangladesh.
}

${ }^{4}$ Department of Gynae \& Obstetrics Chittagong Medical College, Chittagong, Bangladesh.
*Correspondence to:

\section{Dr. M. Shahab Uddin Ahamad}

Department of Pathology

Cox's Bazar Medical College

Cox's Bazar, Bangladesh.

Email:ahamad.shahab@yahoo.com

\begin{abstract}
Aim: To describe the technique and findings of fine needle aspiration cytology (FNAC) of the testes for the assessment of azoospermic male infertility. Methods: Fifty four azoospermic patients were included in this study. A single dose of diclofenac sodium $(50 \mathrm{mg})$ Supository was given per rectally half an hour before aspiration. The FNA was done on both testes under surface anesthesia with 23G needle attached to a $10 \mathrm{ml}$ disposable syringe. Aspirated smears were stained with H\&E. Results: Normal spermatogenesis in both testes was found in $6(11.11 \%)$, only in right testis $03(5.55 \%)$ and only in left testis 03(5.55\%) cases. Hypo spermatogenesis in $07(12.96 \%)$ cases . Sertoli cell syndrome in 05(9.26\%) and maturation arrest in $30(55.60 \%)$ cases. No significant complications were noted.

Conclusion: FNAC of testis is a simple, well tolerated and informative procedure in assesing azoospermia.
\end{abstract}

Key words: FNAC; testis; azoospermia.

\section{INTRODUCTION}

In the assessment of male infertility, semen analysis is the most accepted initial investigation for evaluation of testicular function. Azoospermia is present in 10-15\% of men evaluated for infertility ${ }^{1}$. Until recently testicular biopsy was the standard method for ascertaining the aetiology of azoosermia ${ }^{2}$. However, it requires a surgical procedure that is usually performed under general anaesthesia. As an alternative, testicular fine needle aspiration (FNA) has gained increasing popularity as a simple, minimally invasive and rapid technique that can be performed on an outpatient basis and also that can help in assessing testicular function accurately ${ }^{2-3}$. Aspiration of testis was advocated in the initial decades of $19^{\text {th }}$ century ${ }^{4}$. However, the technique was generally ignored due to limited awareness of the usefulness of the technique and lack of expert cytopathologist $t^{5}$. We describe our tehniques and findings in a series of FNAC from testes of azoospermic patients.

\section{MATERIALS \& METHODS}

This descriptive study was performed on 54 azoospermic patients who attended in a private diagnostic laboratory of Chittagong, Bangladesh, during the period of January 2012 to June 2013. FNA of testis was done after explaining the procedure and possible complications. A single dose of diclofenac sodium (50mg) suppository was given per rectally half an hour before aspiration. Aspiration was done on both testes under aseptic conditions. The FNA was performed under surface anaesthesia by lidocaine (topical aerosol) USP 15\% w/w, with 23 gauge needle attached to a $10 \mathrm{ml}$ disposable syringe. The aspirate smears were then wet fixed in $95 \%$ alcohol and stained with H\&E stain. The smears were examined under microscope and classified as normal spermatogenesis (all the cells of spermatogenesis are present. The ratio of spermatogenic to sertoli cell is at least 1.5:1), hypospermatogenesis (relative decrease of cells of spermatogenesis is present. The ratio of spermatogenic to sertoli cell is less than 1.5:1), sertoli cell syndrome (smears show mainly sertoli cell, no germ cell) and maturation arrest (all types of germ cells except spermatozoa are present). 


\section{RESULTS}

The mean age of these patients was 32.7 years with a range of 24 to 50 years. All cases were primary infertility. No one had clinically varicocele, obstruction or growth. Bilateral aspiration was done in all cases.

Out of 54 patients, normal spermatogenesis in both testes was found in $06(11.11 \%$ ) cases, only in right testis $03(5.55 \%)$ and only in left testis $03(5.55 \%)$ cases. Hypospermatogenesis in both testes was found in $07(12.96 \%)$ cases. Sertoli cell syndrome and maturation arrest were found in $05(9.26 \%)$ and $30(55.56 \%)$ cases respectively (Table 1$)$.

During aspiration, 06(11.11\%) showed mild pain, 47(87.05\%) moderate pain and $1(1.85 \%)$ severe pain. No one complained prolonged pain (more than 15 minutes) or haematoma formation.

Table 1: Findings of FNAC in 54 cases.

Findings

Number of cases $(\%)$

Normal spermatogenesis

$\begin{array}{lc}\text { In both testes } & 06(11.11 \%) \\ \text { Only in right testis } & 03(5.55 \%) \\ \text { Only in left testis } & 03(5.55 \%) \\ \text { Hypospermatogenesis } & 07(12.96 \%) \\ \text { Sertoli cell syndrome } & 05(9.26 \%) \\ \text { Maturation arrest } & 30(5556 \%) \\ \text { Total } & 54(100 \%)\end{array}$

\section{DISCUSSION}

There is a good correlation between histology of the testis and FNAC, resulting the later is gaining more popularity ${ }^{2-3} \& 5-7$. The heterogeneity of the spermatogenetic process within the testis as well as between two testes requires sampling of both testes and multiple puncture. Single aspirate may not be truly representative ${ }^{8}$. However, some studies have described sampling of only one testis ${ }^{6,9}$. The study used sampling of both testes and findings are also different in both testes.

In our study normal spermatogenesis found in total $22.22 \%$ cases, hypospermatogenesis in $12.96 \%$ cases. This findings correlates with the finding of Adhikari RC, Rajwanshi A et al and Qublan HS et $\mathrm{al}^{6,7,10}$. However, we found maturation arrest in $55.56 \%$ cases and sertoli cell syndrome in $9.26 \%$ cases, which does not correlate with others ${ }^{6,7,10}$.

Most of the authors have performed FNA under general anaesthesia or local anaesthesia (cord block). Verma AK et al performed FNA without general or local anaesthetic and found the technique is well tolerated by the most patients ${ }^{11}$. We also used no general or local anaesthetic and well tolerated by the patient. Adhikary RC observed severe pain after FNA procedure in 32 out of 101 patients and haematoma in 03 patients ${ }^{6}$. Rajwanshi et al observed only complication was prolonged pain in some patients, which responded to scrotal support and analgesics ${ }^{7}$. In our study we noted severe pain in 01 patient. No prolonged pain or haematoma formation was found.

\section{CONCLUSION}

FNAC of testis is a simple, well tolerated and informative procedure in assessing azoospermia.

\section{DISCLOSURE}

All the authors declared no competing interest. 


\section{REFERENCES}

1. Jarow JP, Espeland MA, Lipshultz L1. Evaluating of the azoospermic patient. J urol 1989; 142: 62-5.

2. Mehrotra R, Chaurasia D. Fine needle aspiration cytology of the testis as the first line diagnostic modality in azoospermia : a comparative study of cytology and histology. Cytopathology 2008;19:363-368.

3. Ali MA, Akhtar M. Woodhouse $\mathrm{N}$ et al. Role of testicular fine needle aspiration biopsy in the evaluation of male infertility : Cytologic and Histologic correlation. Diagn cytopathol, 1991;7(2): 128-131.

4. Huhner M. Aspiration of testicles in the fiagnosis and prognosis of sterility. J Urol 1928;9: 31-41.

5. Kumar R, Gautam G, Gupta NP et al. Role of testicular fine needle aspiration cytology in infertile men with clinically obstructive azoospermia. Natl Med J India 2006;19:18-20.

6. Adhikary RC. Testicular fine needle aspiration cytology in azoospermic males. Nepal Med Coll J 2009;11(2):88-91.

7. Rajwanshi A, Indudhara R, Goswami AK et al. Fine needle aspiration cytology in azoospermic males. Diagn Cytopathol 1991;7:3-6.

8. Skakkeback NE, Hammen R, Philip H, Rebbe H. Quantitation of human seminiferous epithelium. Histological studies in 44 infertile men and controls with normal chromosomal complements. Acta pathol Microbiol scand 1973;81:97-111.

9. Mahajan AD, Ali NI, Walwalker SJ, Rege JD, Pathak HR. The role of fine needle asiration cytology of the testis in the diagnostic evaluation of infertility. Brit J Urol Intl 1999;84:485-8.

10. Qublan HS,AL-Jader KM, AL Kaisi NS et al. fine needle aspiration cytology compared with open biopsy histology for the diagnosis of azoosermia. J obst Gynaecol 2002;22(5):527-531.

11. Verma AK, Basu D, Jayaram G. Testicular cytology in azoospermia. Diagn Cytopathol 1993;9:37-42. 